\title{
Clinical relevance of genetic instability in prostatic cells obtained by prostatic massage in early prostate cancer
}

\section{R Thuret', K Chantrel-Groussard ${ }^{2}$, A-R Azzouzi ${ }^{1,3}$, J-M Villette ${ }^{4}$, S Guimard ${ }^{5}$, P Teillac ${ }^{6}$, P Berthon ${ }^{2}$, A Houlgatte ${ }^{7}$, A Latil ${ }^{2}$ and $O$ Cussenot $^{*, 1,8}$}

'CeRePP-EA3104, University Paris 7, France; ${ }^{2}$ UroGene (R), Génopole, Evry, France; ${ }^{3}$ Department of Urology of La Pitié-Salpêtrière Hospital, Paris, France; ${ }^{4}$ department of Hormonal Biology, Saint-Louis Hospital, Paris, France; ${ }^{5}$ Research Laboratory of Pathology-EA2378, Academic Institute of Hematology, Saint-Louis Hospital, Paris, France; ${ }^{6}$ Department of Urology, Saint-Louis Hospital, Paris, France; ${ }^{7}$ Department of Urology, Val-de-Grâce Hospital, Paris,

France; ${ }^{8}$ Department of Urology, Tenon, Paris, France

We investigated whether genetic lesions such as loss of heterozygosity $(\mathrm{LOH})$ are detected in prostatic cells obtained by prostatic massage during early diagnosis of prostate cancer (CaP) and discussed their clinical relevance. Blood and first urine voided after prostatic massage were collected in 99 patients with total prostate-specific antigen (PSA) between 4 and $10 \mathrm{ng} \mathrm{ml}^{-1}$, prior to prostate biopsies. Presence of prostatic cells was confirmed by quantitative RT-PCR analysis of PSA mRNA. Genomic DNA was analysed for $\mathrm{LOH}$ on six chromosomal regions. One or more allelic deletions were found in prostatic fluid from 57 patients analysed, of whom 33 (58\%) had CaP. Sensitivity and specificity of $\mathrm{LOH}$ detection and PSA free to total ratio $<15 \%$ for positive biopsy were respectively 86.7 and $44 \%(P=0.002)$ for $\mathrm{LOH}$, and 55 and $74 \%(P=0.006)$ for PSA ratio $<15 \%$. Analysis of $\mathrm{LOH}$ obtained from prostatic tumours revealed similar patterns compared to prostatic fluid cells in $86 \%$ of cases, confirming its accuracy. The presence of LOH of urinary prostatic cells obtained after prostatic massage is significantly associated with CaP on biopsy and may potentially help to identify a set of patients who are candidates for further prostate biopsies.

British Journal of Cancer (2005) 92, 236-240. doi: I0.1038/sj.bjc.66023 I I www.bjcancer.com

Published online II January 2005

(C) 2005 Cancer Research UK

Keywords: biomarker; diagnosis; localised cancer; $\mathrm{LOH}$

Prostate cancer $(\mathrm{CaP})$ is one of the most common cancers in men in Western countries and is second in terms of mortality (Greenlee et al, 2000). During the year 2000, in Europe, 189466 new cases of $\mathrm{CaP}$ were diagnosed with $81353 \mathrm{CaP}$-related deaths. In order to reduce mortality, prostate cancer should be diagnosed at an early stage when the tumour is still organ confined. Whereas the treatment of advanced $\mathrm{CaP}$ is inefficient, an organ-confined tumour can be cured by radical prostatectomy, radiotherapy or cryotherapy.

The early detection of $\mathrm{CaP}$ is actually carried out by the association of digital rectal examination (DRE) and serum total prostate-specific antigen (tPSA) level. The usual upper limit for tPSA is $4 \mathrm{ng} \mathrm{ml}^{-1}$. However, between 4 and $10 \mathrm{ng} \mathrm{ml}^{-1}$, there exists a diagnostic grey zone with an estimated probability of only $40 \%$ of $\mathrm{CaP}$ in men with normal findings on DRE. Prostrate cancer can only be accurately differentiated from benign prostate hyperplasia (BPH) by pathological proof, usually obtained by prostatic biopsies (PB). To refine the indications for $\mathrm{PB}$, and therefore to reduce morbidity, new indicators based on tPSA were developed: age-adjusted tPSA cutoffs, tPSA velocity or tPSA density where the

\footnotetext{
* Correspondence: Professor $O$ Cussenot, CeRePP, Faculté de Médecine des Saints-Peres, 45 rue des Saints-Peres, F-75006 Paris, France; E-mail: o.cussenot@cerepp.org

Received 8 April 2004; revised 8 November 2004; accepted 8 November 2004; published online II January 2005
}

elevated tPSA is indexed to the gland size (Brawer, 1999). The most commonly used indicator is free/total PSA ratio (f/tPSA), which may help to predict $\mathrm{CaP}$ or $\mathrm{BPH}$ in its extreme values (Catalona et al, 1997). However, the probability of CaP at biopsy among men with a PSA value between 4 and $10 \mathrm{ng} \mathrm{ml}^{-1}$ and normal findings on DRE ranged from $56 \%$ for men with an f/tPSA ratio of $<10 \%$ to $8 \%$ for men with a ratio $>25 \%$ (Catalona et al, 1998), underlying the lack of accuracy of the f/tPSA indicator. The difficulty of estimating the risk of $\mathrm{CaP}$ when there is a suspicious DRE without nodule, when tPSA ranges between 4 and $10 \mathrm{ng} \mathrm{ml}^{-1}$ or when f/tPSA has an average value (between 15 and 25\%), taken together with the morbidity due to $\mathrm{PB}$, highlights the need of new predictive markers for $\mathrm{CaP}$.

Several authors have used prostatic fluid to develop new diagnostic markers for CaP. Recently, investigators examined the presence of glutathione $S$-transferase (GSTP1) hypermethylation in shed neoplastic cells and urinary debris (Cairns et al, 2001). However, its sensitivity (27\%) is too low for clinical practice. Telomerase activity was detected after prostatic massage in freshly voided urine (Meid et al, 2001), but this approach did not reach clinical practice because of low sensitivity (40\%) for the detection of low-grade tumours. The evaluation of ornithine-decarboxylase (ODC) expression in prostatic fluid after prostatic massage has shown an uptranscriptional regulation in CaP (Mohan et al, 1999), but intraindividual variations have been observed. Interestingly, the quantification in urine samples after prostatic massage of the CaP-specific gene DD3 (PCA3) transcripts has shown a sensibility 
and a specificity of respectively $67 \%$ and $83 \%$ (Hessels et al, 2003). Presently, one limit of the clinical acceptance of tests based on quantification of transcripts in urinary sample is the need to preserve RNA quality and to manage immediate frozen sample in clinical pratice. Urinary tests based on DNA sample, like microsatellite analysis or FISH, have already shown their ability to detect bladder carcinoma in clinical practice.

Loss of heterozygosity ( $\mathrm{LOH})$ is the most frequent genetic abnormality in $\mathrm{CaP}$. Recurrent $\mathrm{LOH}$ in $\mathrm{CaP}$ has been found on chromosome arms $7 \mathrm{q}, 8 \mathrm{p}, 10 \mathrm{q}, 12 \mathrm{p}, 13 \mathrm{q}, 16 \mathrm{q}, 17 \mathrm{q}$ and $18 \mathrm{q}$, suggesting the presence of tumour suppressor genes (Gao et al, 1995; Latil et al, 1999; Elo and Visakorpi, 2001). Although these tumour suppressor genes are unknown, we have previously shown accurate detection of $\mathrm{CaP}$ by investigating genetic alterations in prostatic cells collected in urinary sediments (Cussenot et al, 2001). Furthermore, prognostic significance has been associated with deletions on chromosome $8 \mathrm{p} 22$, which predicts disease progression (Matsuyama et al, 2001), and on 12pl2-13 and 13q, which predicts aggressiveness (Dong et al, 2000; Kibel et al, 2000). In order to extend our previous work (Fromont et al, 2003), the aim of this study was to develop a new noninvasive method to detect early stages of CaP using $\mathrm{LOH}$ analysis of $7 \mathrm{q} 31,8 \mathrm{p} 22,12 \mathrm{pl} 3$, $13 \mathrm{ql}, 16 \mathrm{q} 23.2$ and 18q21. We have analysed these six regions in prostatic cells collected in urinary sediments after prostatic massage for $\mathrm{LOH}$, and compared them with the f/tPSA values and results of prostatic biopsy.

\section{PATIENTS AND METHODS}

\section{Patients' selection}

Samples were collected in two separated centres. Men who presented with suspected $\mathrm{CaP}$ requiring $\mathrm{PB}$ were included in this study. CaP was suspected with a PSA $>4 \mathrm{ng} \mathrm{ml}^{-1}$ and/or suspicious DRE. Patients with a tPSA over $10 \mathrm{ng} \mathrm{ml}^{-1}$ or with evident clinical T3 CaP at DRE were excluded, as well as men with a history of urothelial tumours. Agreement for this clinical trial was obtained from the ethics committee of Paris-StLouis (CCPPRB No. 2000/69-29/12/2000). Informed consent was obtained from each patient.

A total of 99 patients (mean: 65.4 years; s.d.: 7.5 ) with a tPSA (mean: $6.7 \mathrm{n} \mathrm{ml}^{-1}$; s.d.: 1.76) in the diagnostic grey zone (4$10 \mathrm{ng} \mathrm{ml}^{-1}$ ) were analysed for f/tPSA ratio (mean: 16.1 ; s.d.: 5.9 ) and the presence of $\mathrm{LOH}$ in prostatic fluid cells. All had, at least sextant, transrectal ultrasound-guided $\mathrm{PB}$.

\section{Sample collection}

Venous blood was collected from each patient for both PSA measurement and DNA extraction. Prostrate-specific antigen measurements were performed in the Saint-Louis hospital department of hormonal biology for every sample with PSA-RIACT and FPSA-RIACT (CIS bio International, Gif-s/-Yvette, France).

Urinary sediments were obtained after prostatic massage performed by DRE. Prostatic massage was performed in order to obtain prostatic secretion at the urethral meat. The first urine voided was collected to extract both RNA and DNA. Urinary samples were centrifuged for $30 \mathrm{~min}$ at $4^{\circ} \mathrm{C}(850 \mathrm{~g})$, before the cell pellets were immediately stored at $-80^{\circ} \mathrm{C}$.

In 19 of these cases, formalin-fixed and paraffin-embedded prostatic samples from the patient's radical prostatectomy specimen were also analysed (Table 1). In six of these specimens, lasercapture microdissection was used to obtain 'normal' prostatic epithelial cells, close to the tumour, for $\mathrm{LOH}$ analysis. In each of these samples, prostatic fluid cells and tumour were also analysed (Table 1). Cells were catapulted in $20 \mu \mathrm{l}$ of $1 \times$ lysis buffer (for $1 \mathrm{ml}$ of lysis buffer: Tris $2 \mathrm{~m} \mathrm{pH} 825 \mu$ l, EDTA $0.5 \mathrm{~m} 2 \mu$ l, Tween $205 \mu \mathrm{l}$, proteinase $\mathrm{K} \quad 50 \mu \mathrm{l}$ and $\mathrm{H}_{2} \mathrm{O} \quad 918 \mu \mathrm{l}$ ) (PALM Micro Laser Technologies, Bernried, Germany).

PCR protocol and genotyping analysis are described below.

\section{Nucleic acid extractions}

All the products used in this study were from SIGMA, (St Louis, MO, USA) unless specified otherwise.

Two distinct methods were used for blood lymphocyte DNA and prostatic cell DNA extraction.

A cell lysis was obtained from blood by red corpuscle lysis solution (Tris $2 \mathrm{M} \mathrm{pH} \mathrm{7.6,} \mathrm{NaCl} 3 \mathrm{M}, \mathrm{MgCl}_{2} 1 \mathrm{M}, \mathrm{H}_{2} \mathrm{O}$ ). After centrifugation $\left(10 \mathrm{~min}, 24^{\circ} \mathrm{C}, 1200 \mathrm{~g}\right)$, a white corpuscle lysis solution (Tris $1 \mathrm{~m} \mathrm{pH} \mathrm{7,} \mathrm{NaCl} 3 \mathrm{~m}$, EDTA $0.4 \mathrm{M}$, SDS $10 \%, \mathrm{H}_{2} \mathrm{O}$ ) was added to the pellet; proteins were precipitated and pelleted by centrifugation $\left(10 \mathrm{~min}, 24^{\circ} \mathrm{C}, 1200 \mathrm{~g}\right)$ with $10 \mathrm{M}$ ammonium acetate. DNA precipitation was obtained by adding cold isopropanol to the supernatant. After centrifugation ( $5 \mathrm{~min}$ and $1200 \mathrm{~g}$ ), the DNA pellet was rinsed with $70 \%$ ethanol and recentrifuged. DNA was suspended in TE 10-1 (Tris $2 \mathrm{M} \mathrm{pH} \mathrm{7.6,} \mathrm{EDTA} 0.4 \mathrm{M}, \mathrm{H}_{2} \mathrm{O}$ ) under slow agitation at $42^{\circ} \mathrm{C}$ for $48 \mathrm{~h}$. DNA concentration was calculated by spectrophotometry (DU $640 \mathrm{~B}$, Beckman, USA) at $260 \mathrm{~nm}$ and adjusted to $200 \mathrm{ng} \mathrm{l}^{-1}$.

Prostatic cell DNA was obtained using phenol-acid/chloroform extraction, after proteinase $\mathrm{K}$ treatment of the microdissected tumour cells.

RNA extraction was performed only from urinary sediments according to Chomczynski's method (Chomczynski and Sacchi, 1987). RNA was stored at $-80^{\circ} \mathrm{C}$ in DEPC-treated water.

\section{RNA analysis}

To determine the presence of prostatic cells and their proportion compared with other cell types, RNA analysis was performed by quantitative real-time PCR after reverse transcription (RT).

After a first RNA incubation ( $1 \mu \mathrm{l}$ of total RNAs in $3 \mu \mathrm{l}$ DEPC water for $5 \mathrm{~min}$ at $57^{\circ} \mathrm{C}$ ), RT was performed with $16 \mu \mathrm{l}$ of reaction mix (buffer $5 \times 4 \mu \mathrm{l}$, DTT $0.1 \mathrm{~mm} 2 \mu \mathrm{l}$, DNTP $10 \mathrm{~mm}$ each $1 \mu \mathrm{l}$, Rhex $6 \mu \mathrm{l}$, RNAsin $0.5 \mu \mathrm{l}$, Superscript II $0.5 \mu \mathrm{l}$ and $\mathrm{H}_{2} \mathrm{O} 2 \mu \mathrm{l}$ ) by three cycles of incubation: $10 \mathrm{~min}$ at $20^{\circ} \mathrm{C}, 30 \mathrm{~min}$ at $42^{\circ} \mathrm{C}$ and $5 \mathrm{~min}$ at $99^{\circ} \mathrm{C}$ (Peltier Thermal Cycler-200, MJ Research, INC Massachussets, USA).

Quantification of prostate-specific mRNA encoding PSA ( $5^{\prime}$-acc aga gga gtt ctt gac ccc aaa- $3^{\prime} ; 5^{\prime}-c c c$ cag aat cac ccg agc ag- $\left.3^{\prime}\right)$ and transcripts of PPIA (peptidylprolyl isomerase A gene encoding cyclophilin A) gene, used as an endogenous RNA control ( $5^{\prime}$-gtc aac ccc acc gtg ttc tt $-3^{\prime} ; 5^{\prime}$-ctg ctg tct ttg gga cct tgt- $\left.3^{\prime}\right)$, was performed by means of the SYBR ${ }^{\circledR}$ Green PCR Core Reagents kit (Applied Biosystems, Palo Alto, CA, USA) using an ABI Prism 7700 Sequence Detection System (Applied Biosystems, Palo Alto, CA, USA). To determine which samples had a sufficient proportion of prostatic cells for genetic analysis, we ensured that the PPIA and PSA mRNA levels corresponded to a straight line (Ct PPIA $=0.386$ Ct PSA + 13.82) (data not shown). In total, 82 samples contained a satisfactory proportion of prostatic cells for genotyping analysis.

\section{Genotyping analysis}

Extracted DNA from blood and prostatic cells was amplified by PCR, using 14 microsatellite markers localised on chromosome arms 7q31, 8p22, 12pl3, 13ql4, 16q23.2. and 18q21: D7S480, D7S522, D7S523, D8S261, D8S1786, D12S77, D12S358, D13S153, D13S272, D13S284, D16S507, D16S518 (Dib et al, 1996), and D18S39, D18S46 (Straub et al, 1993). PCR amplification was carried out with $3 \mathrm{ng}$ of DNA in a $20 \mu \mathrm{l}$ final volume of reaction mix (dNTP $0.25 \mathrm{~mm}$, Tris $1 \mathrm{M}$, boric acid $0.9 \mathrm{M}$, EDTA $0.01 \mathrm{M}, 20 \mathrm{pmol}$ of each primer (MWG Biotech, Ebersberg, Germany), $0.75 \mu \mathrm{l}$ of DMSO, Taq polymerase $1 \mathrm{U}$ (Qbiogen, Illkirch, France)). The PCR 
Table I Results of the 14 loci tested on desquaming prostatic cell DNA according to PB results and in comparision with LOH in tumoral and nontumoral DNA cells from prostate specimens

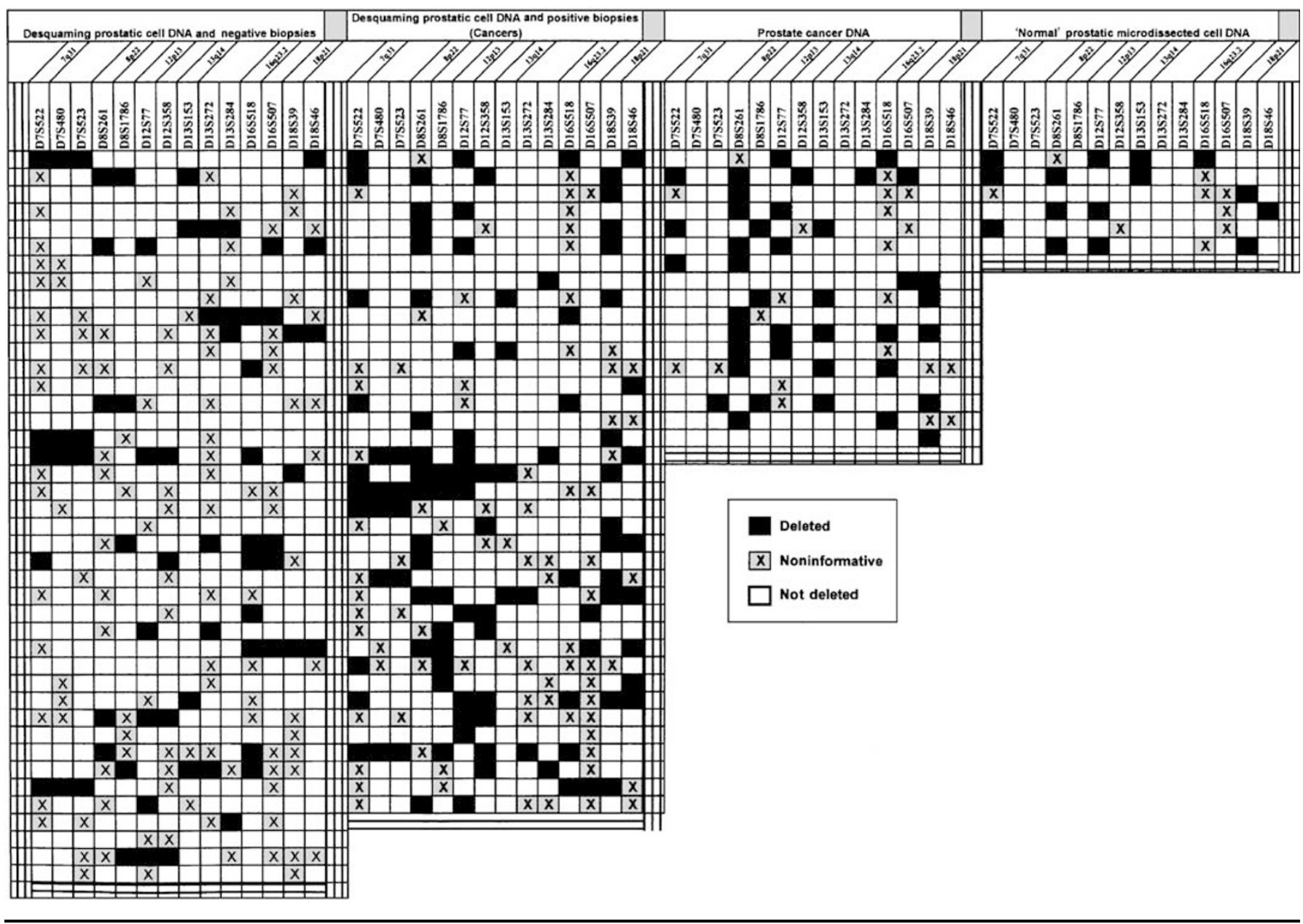

protocol was previously described (Berthon et al, 1998) and annealing temperature was optimised for each primer.

Then, $1 \mu \mathrm{l}$ of PCR product was added to $1 \mu \mathrm{l}$ of blue dextran and $3 \mu \mathrm{l}$ of formamide. After a 2 min denaturation at $94^{\circ} \mathrm{C}$, amplified fragments were analysed on an automatic sequencer (377 DNA sequencer, Applied Biosystems, Palo Alto, CA, USA) by electrophoresis in TBE buffer (Tris $0.089 \mathrm{M}$, borate $0.089 \mathrm{M}$, EDTA $0.002 \mathrm{M}$ $\mathrm{pH} 8$ ) through a $4 \%$ polyacrylamide (Acryl/Bisacryl 29/1) $6 \mathrm{M}$ urea gel. Analysis was performed by GeneScan 3.1 Fragment Analysis Software (Applied Biosystems, Palo Alto, CA).

Loss of heterozygosity was considered to be present when the relative intensity of the two alleles in urinary sample DNA differed from the relative intensity in leuckocyte DNA by a factor of at least 1.3. This threshold, which is suitable for tumour LOH detection (Zenklusen et al, 1994), can also be used for the urinary sediments of this study because of the quality selection criteria applied on the samples (see RNA analysis). Each LOH analysis was performed at least twice (repeated PCR amplification, gel separation, and quantification).

\section{Statistical analysis}

All statistical analyses were performed by using the $\chi^{2}$ test with the SAS software (version 6.12;. SAS Institute Inc., Cary, NC, USA). All $P$-values were determined by two-sided tests. $P$-values less than 0.05 were considered to be statistically significant.

\section{RESULTS}

Out of 99 patients included in this study, a set of 81 patients had a sufficient proportion of prostatic cells in urinary sediment to perform LOH analysis, of which 38 had CaP on PB (Tables 1 and 2 ). The distribution of age, tPSA and f/tPSA ratio in the group with and without positive biopsy were: negative biopsy: age 65.2 s.d. 5.8; tPSA 6.7 s.d. 1.8; f/tPSA 18.2 s.d. 6.0 ; positive biopsy: age 66.5 s.d. 9.2; tPSA 6.7 s.d. 1.7 ; f/tPSA 13.8 s.d. 5.3. Allelic deletions were founded for 57 patients, of whom $33(58 \%)$ had CaP. Within this group, $\mathrm{LOH}$ detection had an $87 \%$ sensibility and $44 \%$ specificity (Table 1).

Then, we checked the validity of the LOH test in urinary sediments by comparing them with the $\mathrm{LOH}$ of the corresponding tumours in 19 patients (Table 1). We defined three classes of results: strictly identical results with the same patterns of $\mathrm{LOH}$ in tumour and urinary sediments; concordant results in which identical patterns were seen in the two samples except for additional tumour $\mathrm{LOH}$; discordant results corresponded to $\mathrm{LOH}$ observed in urinary sediment but not in the tumour. The comparison between the two samples has shown that identical LOH was present in $70.6 \%$ and concordant results in $86 \%$. Only $14 \%$ of the results were discordant $(28.1 \%$ of them concerned the $16 \mathrm{q} 23.2$ region markers). We investigated also the hypothesis that genetic alterations could exist prior to a morphological abnormality. Therefore, the genetic status of histologically 'normal' prostatic cells located near the tumour was analysed. In total, 
Table 2 Pathological patterns of cancers on biopsies and markers (tPSA, f/tPSA, number of LOH)

\begin{tabular}{|c|c|c|c|c|c|c|c|}
\hline Age & tPSA & f/tPSA & $\begin{array}{c}\text { Number } \\
\text { of LOH }\end{array}$ & $\begin{array}{l}\text { Gleason } \\
\text { score from } \\
\text { biopsy }\end{array}$ & Grade I & Grade 2 & $\begin{array}{c}\text { Stage } \mathrm{pT}^{\mathrm{a}} \\
\text { from } \\
\text { biopsy }\end{array}$ \\
\hline 73 & 6 & 7 & I & 5 & 3 & 2 & $2 a$ \\
\hline 84 & 8 & 20 & 2 & 7 & 4 & 3 & $2 b$ \\
\hline 56 & 6 & 19 & 2 & 4 & 2 & 2 & $2 \mathrm{a}$ \\
\hline 63 & 7 & 15 & 2 & 6 & 3 & 3 & $2 \mathrm{a}$ \\
\hline 66 & 4 & 15 & 2 & 6 & 3 & 3 & $2 a$ \\
\hline 58 & 6 & 8 & 2 & 6 & 3 & 3 & $2 \mathrm{a}$ \\
\hline 69 & 10 & | | & 3 & 6 & 3 & 3 & $2 b$ \\
\hline 81 & 7 & 11 & I & 6 & 3 & 3 & $2 a$ \\
\hline 72 & 7 & 7 & I & 6 & 3 & 3 & $2 a$ \\
\hline 75 & 6 & 16 & I & 6 & 3 & 3 & $2 a$ \\
\hline 58 & 7 & 6 & 0 & 7 & 4 & 3 & $2 b$ \\
\hline 61 & 8 & 27 & 1 & 4 & 2 & 2 & $2 \mathrm{a}$ \\
\hline 64 & 4 & 22 & 5 & 6 & 3 & 3 & $2 a$ \\
\hline 68 & 7 & 7 & 1 & 6 & 3 & 3 & $2 b$ \\
\hline 56 & 7 & 17 & 5 & 4 & 2 & 2 & $2 a$ \\
\hline 57 & 6 & 25 & 5 & 6 & 3 & 3 & $2 a$ \\
\hline 66 & 5 & 17 & 2 & 5 & 3 & 2 & $2 a$ \\
\hline 59 & 8 & 15 & 3 & 4 & 2 & 2 & $2 \mathrm{a}$ \\
\hline 75 & 8 & 15 & 0 & 5 & 2 & 3 & $2 b$ \\
\hline 72 & 6 & 14 & I & 5 & 2 & 3 & $2 \mathrm{a}$ \\
\hline 69 & 6 & 17 & 3 & 5 & 2 & 3 & $2 \mathrm{a}$ \\
\hline 73 & 9 & 10 & 2 & 8 & 4 & 4 & $2 a$ \\
\hline 67 & 5 & 15 & 1 & 7 & 3 & 4 & $2 b$ \\
\hline 56 & 6 & 10 & 2 & 7 & 4 & 3 & $2 b$ \\
\hline 70 & 8 & 12 & 3 & 6 & 3 & 3 & $2 a$ \\
\hline 56 & 6 & 7 & 2 & 6 & 3 & 3 & $2 \mathrm{a}$ \\
\hline 67 & 5 & 17 & 3 & 6 & 3 & 3 & $2 \mathrm{a}$ \\
\hline 93 & 5 & 8 & 1 & 8 & 4 & 4 & $2 b$ \\
\hline 73 & 7 & 16 & 3 & 6 & 3 & 3 & $2 \mathrm{a}$ \\
\hline 66 & 4 & 15 & 4 & 6 & 3 & 3 & $2 \mathrm{a}$ \\
\hline 60 & 6 & 24 & 1 & 5 & 3 & 2 & $2 \mathrm{a}$ \\
\hline 58 & 6 & 17 & 1 & 7 & 4 & 3 & $2 b$ \\
\hline 58 & 7 & 14 & 0 & 6 & 3 & 3 & $2 \mathrm{a}$ \\
\hline 70 & 8 & 13 & 3 & 7 & 4 & 3 & $2 c$ \\
\hline 81 & 10 & 12 & 0 & 7 & 4 & 3 & $2 c$ \\
\hline 69 & 8 & 13 & 2 & 6 & 3 & 3 & $2 c$ \\
\hline 49 & 9 & 8 & 0 & 7 & 3 & 4 & $2 c$ \\
\hline 59 & 10 & 8 & 2 & 5 & 2 & 3 & $2 c$ \\
\hline
\end{tabular}

${ }^{a} \mathrm{p} T 2 \mathrm{a}=$ Positive biopsies in one prostatic lobe, less than half-lobe, $\mathrm{pT} 2 \mathrm{~b}=$ positive biopsies in one prostatic lobe, more than half-lobe, $\mathrm{p} T 2 \mathrm{c}=$ positive biopsies in the two prostatic lobes (according to UICC, TNM 2002).

Table 3 Diagnostic parameters of the genetic test $(\mathrm{LOH})$ and f/tPSA ratios (threshold values: 15, 20 and $25 \%$ ) for 81 patients with a total PSA between 4 and $10 \mathrm{ng} \mathrm{ml}^{-1}$

\begin{tabular}{lccc}
\hline & Sensitivity $\%$ & Specificity $\%$ & $\chi^{\mathbf{2}}$ (P-value) \\
\hline Genetic test $($ LOH $)$ & 87 & 44 & $P=0.002$ \\
f/tPSA $<25 \%$ & 95 & 12 & $P=0.309$ \\
f/tPSA $<20 \%$ & 86 & 33 & $P=0.09$ \\
f/tPSA $<15 \%$ & 55 & 74 & $P=0.006$ \\
LOH or f/tPSA $<15 \%$ & 100 & 32 & $P=0.06$ \\
\hline
\end{tabular}

$53.3 \%$ of allelic deletions observed in tumour DNA were present in the histologically normal prostatic cells (Table 1).

Genetic diagnosis using $\mathrm{LOH}$ has been compared to f/tPSA ratios of $<25,<20$ and $<15 \%$, which are considered as the best indicators of $\mathrm{CaP}$ (Table 2). Only seven patients (8.6\%) had an $\mathrm{f} /$ tPSA ratio over two $5 \%$, two of which had CaP. Using the $<15 \%$ cutoff, the f/tPSA ratio had a sensitivity of $50 \%$ and specificity of $77 \%$, which discriminates significantly $(P=0.006)$ the group with $\mathrm{CaP}$ (Table 3). All cancers could be detected if $\mathrm{f} / \mathrm{tPSA}<15 \%$ or $\mathrm{LOH}$ was used, and in these conditions the specificity was $32 \%$.
Out of the 81 patients (of whom five had a CaP), 25 did not have any $\mathrm{LOH}$ detected. In each case, they had an f/tPSA threshold $<15 \%$. Of the 81 patients, 57 had one or more $\mathrm{LOH}$, of which 31 had CaP. None of these patients had LOH in all six chromosomal regions. The frequency of 1-3 chromosomal LOHs was not significantly related to the presence of $\mathrm{CaP}$. Of the patients, 56 and $61 \%$ respectively had positive biopsies among patients with (one or two) LOH and over three altered regions.

\section{DISCUSSION}

By this clinical trial, using early $\mathrm{CaP}$, we have shown that $\mathrm{LOH}$ can be found in cells obtained from urine by prostatic massage. In particular, $\mathrm{LOH}$ can be found at hotspot loci associated with $\mathrm{CaP}$, in patients with positive $\mathrm{PB}$.

Assuming that a positive biopsy is the gold standard, the statistical parameters of the $\mathrm{CaP}$ detection by the $\mathrm{LOH}$ analysis showed $86.8 \%$ sensitivity for $\mathrm{CaP}$ detection. The fact that the specificity was only $44 \%$ ( 24 false positives) might be due, in part, to the low sensitivity of $\mathrm{PB}$, which is currently estimated between 66 and $85 \%$, and should be close to $83.3 \%$ for a CaP with a volume greater than $2 \mathrm{~cm}^{3}$ (Terris, 1999). This sensitivity varies according to the location of $\mathrm{CaP}$ inside the prostate $(71.4 \%$ for the peripheral zone cancers and $33.3 \%$ for the transition zone cancers). Furthermore, the sensitivity increases by repeated biopsies, underlying the fact that some $\mathrm{CaP}$ are missed by the first set of biopsies. With reference to the experience of $\mathrm{LOH}$ detection in urine during the follow-up of bladder cancer, the specificity should improve with the patients' clinical follow-up.

One of the limitations of the study was the small number of prostate specimens available, as only 19 patients out of 99 underwent a radical prostatectomy. Therefore, the clinical significance of the detected tumours according to tumour volume, Gleason score and presence of adverse pathological patterns such as presence of extracapsular extension and seminal vesicle invasion was unknown.

The presence of genetic alterations in 'normal' cells located near the tumour implies that this test may be useful to detect $\mathrm{CaP}$ at a very early stage or to identify those patients at high risk of developing $\mathrm{CaP}$. Although the roles of multifocality (multiple foci of carcinoma with independent origins) and clonality development (multiple foci of carcinoma in the same prostate derived from a single progenitor) in CaP are still not fully understood, only $11 \%$ of $\mathrm{LOH}$ in normal tissue could not be found in the adjacent tumour, suggesting a monoclonal expansion of cancerous cells. Hügel and Wernert (1999) and Macintosh et al (1998) analysed LOH in different areas of prostate tumour separated by microdissection. They found that a significant proportion of $\mathrm{CaP}$ were made of several histological patterns. However, the clonal or multifocal origin of these patterns was not fully elucidated. Whereas each tumour has its own pattern of $\mathrm{LOH}$, different combinations of genetic events could result in similar malignant phenotypes of $\mathrm{CaP}$.

The sensitivity $(87 \%)$ of $\mathrm{LOH}$ detection for $\mathrm{CaP}$ was higher than that observed for the detection of telomerase activity (40\%) by Meid et al (2001) or for the detection of GSTPl hypermethylation (27\%) by Cairns et al (2001) or quantification of DD3 PCA3 transcripts (67\%) (Hessels et al, 2003).

Some 'false-negative' patients had noninformative loci, because of homozygosity for the marker. This lack of genetic information affected the sensitivity and specificity of $\mathrm{LOH}$ analysis. We analysed urinary samples for $\mathrm{LOH}$ at six different loci known to be frequently altered in prostate tumours, but other chromosomal regions like 16q22.1 have also been shown to be involved in $\mathrm{CaP}$ genesis. The large majority of all molecular mechanisms explaining prostate cancer development are still expected to be discovered.

In order to select those patients likely to have $\mathrm{CaP}$, we have used a noninvasive test based on $\mathrm{LOH}$ detection in cells from prostatic fluid. Furthermore, besides diagnosis value, $\mathrm{LOH}$ detection could 
bring prognostic information on $\mathrm{CaP}$ aggressiveness. A significant correlation would exist between the presence of certain $\mathrm{LOH}$ and relapse after radical prostatectomy. Current follow-up analysis is under way.

\section{REFERENCES}

Berthon P, Valeri A, Cohen-Akenine A, Drelon E, Paiss T, Wohr G, Latil A, Millasseau P, Mellah I, Cohen N, Blanche H, Bellane-Chantelot C, Demenais F, Teillac P, Le Due A, de Petriconi R, Hautmann R, Chumakov I, Bachner L, Maitland NJ, Lidereau R, Vogel W, Fournier G, Mangin P, Cussenot O (1998) Predisposing gene for early-onset prostate cancer, localized on chromosome lq42.2-43. Am J Hum Genet 62: 1416-1424

Brawer MK (1999) Prostate-specific antigen: current status. CA Cancer J Clin 49: 264-281

Cairns P, Esteller M, Herman JG, Schoenberg M, Jeronimo C, SanchezCespedes M, Chow NH, Grasso M, Wu L, Westra WB, Sidransky D (2001) Molecular detection of prostate cancer in urine by GSTP1 hypermethylation. Clin Cancer Res 7: 2727-2730

Catalona WJ, Beiser JA, Smith SD (1997) Serum free prostate specific antigen and prostate specific antigen density measurements for predicting cancer in men with prior negative prostatic biopsies. J Urol 158: $2162-2167$

Catalona WJ, Partin AW, Slawin KM, Naughton CK, Brawer MK, Flanigan RC, Richie JP, Patel A, Walsh PC, Scardino PT, Lange PH, deKernion JB, Southwick PC, Loveland KG, Parson RE, Gasior GH (1998) Use of the percentage of free prostate-specific antigen to enhance differentiation of prostate cancer from benign prostatic disease: a prospective multicenter clinical trial. JAMA 279: 1542-1547

Chomczynski P, Sacchi N (1987) Single-step method of RNA isolation by acid guanidinium thiocyanate-phenol-chloroform extraction. Anal Biochem 162: 156

Cussenot O, Teillac P, Berthon P, Latil (2001) A Noninvasive detection of genetic instability in cells from prostatic secretion as a marker of prostate cancer. Eur J Int Med 12: 17-19

Dib C, Faure S, Fizames C, Samson D, Drouot N, Vignal A, Millasseau P, Marc S, Hazan J, Seboun E, Lathrop M, Gyapay G, Morissette J, Weissenbach J (1996) A comprehensive genetic map of the human genome based on 5,264 microsatellites. Nature 380: 152-154

Dong JT, Chen C, Stultz BG, Isaacs JT, Frierson Jr HF (2000) Deletion at $13 \mathrm{q} 21$ is associated with aggressive prostate cancers. Cancer Res 60: $3880-3883$

Elo JP, Visakorpi T (2001) Molecular genetics of prostate cancer. Ann Med 33: $130-141$

Fromont G, Joulin V, Chantrel-Groussard K, Vallancien G, Guillonneau B, Validire P, Latil A, Cussenot O (2003) Allelic losses in localized prostate cancer: association with prognostic factors. J Urol 170: 1394-1397

\section{ACKNOWLEDGEMENTS}

We thank Dr JWF Catto for critical reading, and $\mathrm{P}$ Lecerf, $\mathrm{M}$ Guérard and $\mathrm{F}$ Plassa for excellent technical assistance.
Gao X, Zacharek A, Salkowski A, Grignon DJ, Sakr W, Porter AT, Honn KV (1995) Loss of heterozygosity of the BRCAl and other loci on chromosome 17q in human prostate cancer. Cancer Res 55: 1002-1005

Greenlee RT, Murray T, Bolden S, Wingo PA (2000) Cancer statistics, 2000. CA Cancer J Clin 50: 7-33

Hessels D, Klein Gunnewiek JM, van Oort I, Karthaus HF, van Leenders GJ, van Balken B, Kiemeney LA, Witjes JA, Schalken JA (2003) DD3(PCA3)based molecular urine analysis for the diagnosis of prostate cancer. Eur Urol 44: 8-15

Hügel A, Wernert N (1999) Loss of heterozygosity (LOH), malignancy grade and clonality in microdissected prostate cancer. Br J Cancer 79: $551-557$

Kibel AS, Faith DA, Bova GS, Isaacs WB (2000) Loss of heterozygosity at $12 \mathrm{P} 12-13$ in primary and metastatic prostate adenocarcinoma. J Urol 164: $192-196$

Latil A, Bieche I, Pesche S, Volant A, Valeri A, Fournier G, Cussenot O, Lidereau R (1999) Loss of heterozygosity at chromosome arm 13q and RBI status in human prostate cancer. Hum Pathol 30: 809-815

Macintosh CA, Stower M, Reid N, Maitland NJ (1998) Precise microdissection of human prostate cancers reveals genotypic heterogeneity. Cancer Res 58: $23-28$

Matsuyama H, Pan Y, Oba K, Yoshihiro S, Matsuda K, Hagarth L, Kudren D, Naito K, Bergerheim US, Ekman P (2001) Deletions on chromosome 8 p22 may predict disease progression as well as pathological staging in prostate cancer. Clin Cancer Res 7: 3139-3143

Meid FH, Gygi CM, Leisinger HJ, Bosman FT, Benhattar J (2001) The use of telomerase activity for the detection of prostatic cancer cells after prostatic massage. J Urol 165: $1802-1805$

Mohan RR, Challa A, Gupta S, Bostwick DG, Ahmad N, Agarwal R, Marengo SR, Amini SB, Paras F, MacLennan GT, Resnick MI, Mukhtar H (1999) Overexpression of ornithine decarboxylase in prostate cancer and prostatic fluid in humans. Clin Cancer Res 5: 143-147

Straub RE, Speer MC, Luo Y, Rojas K, Overhauser J, Ott J, Gilliam TC (1993) A microsatellite genetic linkage map of human chromosome 18. Genomics 15: $48-56$

Terris MK (1999) Sensitivity and specificity of sextant biopsies in the detection of prostate cancer: preliminary report. Urology 54: 486 - 489

Zenklusen JC, Thompson JC, Troncoso P, Kagan J, Conti CJ (1994) Loss of heterozygosity in human primary prostate carcinomas: a possible tumor suppressor gene at 7q31.1. Cancer Res 54: 6370-6373 